\title{
Biological richness of Gunung Slamet, Central Java, and the need for its protection
}

\author{
Christian Devenish, Achmad Ridha Junaid, Andriansyah, Ria Saryanthi \\ S. (Bas) van Balen, Fajar Kaprawi, Ganjar Cahyo Aprianto \\ Richard C. Stanley, Oliver Poole, Andrew Owen \\ N. J. COLLAR and STUART J. MARSDEN
}

\begin{abstract}
Designating protected areas remains a core strategy in biodiversity conservation. Despite high endemism, montane forests across the island of Java are under-represented in Indonesia's protected area network. Here, we document the montane biodiversity of Gunung Slamet, an isolated volcano in Central Java, and provide evidence to support its increased protection. During September-December 2018, we surveyed multiple sites for birds, primates, terrestrial mammals, reptiles, amphibians and vegetation. Survey methods included transects, camera traps and targeted searches at six sites, at altitudes of $970-2,512 \mathrm{~m}$. We used species distribution models for birds and mammals of conservation concern to identify priority areas for protection. We recorded 99 bird species (13 globally threatened), 15 mammals (five globally threatened) and 17 reptiles and amphibians (two endemic). Our species distribution models showed considerable cross-taxon congruence between important areas on Slamet's upper slopes, generally above $1,800 \mathrm{~m}$. Particularly important were records of the endemic subspecies of the Endangered Javan laughingthrush Garrulax rufifrons slamatensis, not recorded in the wild since 1925, the Endangered Javan gibbon Hylobates moloch and Javan surili Presbytis comata, and the Vulnerable Javan lutung Trachypithecus auratus and Javan leopard Panthera pardus melas. Recent forest loss has been modest, at least $280 \mathrm{~km}^{2}$ of continuous forest remain above $800 \mathrm{~m}$, and our surveys show that forest habitats are in good condition. However, the mountain is widely used by trappers and hunters. Given its importance for biodiversity conservation,
\end{abstract}

Christian Devenish (Corresponding author, (1) orcid.org/0000-0002-52490844), Oliver Poole and Stuart J. Marsden Department of Natural Sciences, Manchester Metropolitan University, Chester Street, Manchester, M1 5GD, UK. E-mail c.devenish@mmu.ac.uk

Achmad Ridha Junaid, Andriansyah, Ria Saryanthi, Fajar Kaprawi and Richard C. STANLEY* Burung Indonesia, Bogor, Indonesia

S. (BAS) van BaLen Basilornis Consults, Arnhem, The Netherlands

Ganjar Cahyo Aprianto Faculty of Biology, Jenderal Soedirman University, Purwokerto, Indonesia

Andrew Owen Chester Zoo, Chester, UK

N. J. Collar BirdLife International, Cambridge, UK

${ }^{*}$ Current address: University of Florida, Gainesville, USA

Received 2 June 2020. Revision requested 6 August 2020.

Accepted 15 October 2020. First published online 27 July 2021. we discuss different options for improving the protection status of Gunung Slamet, including designation as a National Park or Essential Ecosystem.

Keywords Conservation planning, Garrulax rufifrons slamatensis, Gunung Slamet, Hylobates moloch, Indonesia, Java, species distribution models, threatened species

Supplementary material for this article is available at doi.org/10.1017/So030605320001222

\section{Introduction}

Tn the face of the current global extinction crisis (Bradshaw et al., 2009; Ceballos et al., 2017), it is vital to establish protected areas that can serve as biological reservoirs for species and ecological processes (Chape et al., 2005; Jenkins \& Joppa, 2009; Le Saout et al., 2013; Venter et al., 2014). Governments, who are primarily responsible for creating and maintaining protected areas, report their progress by reference to Aichi Target 11 of the Convention on Biological Diversity (CBD). However, with the majority of biodiversity concentrated in the tropics, the pressure on developing nations across the equatorial belt to fulfil their $\mathrm{CBD}$ obligations is overwhelming (Chandra \& Idrisova, 2011; Harrop \& Pritchard, 2011; Mallari et al., 2016; Jones et al., 2018). Indonesia is a so-called megadiverse country, with particularly high biological richness on the islands of Borneo, Sumatra and Java, and is considered one of the top three biodiversity hotspots globally because of high levels of both endemism and habitat loss (Mittermeier \& Mittermeier, 1997; Myers et al., 2000). Conserving biodiversity on Java is a particular challenge, with a human population of $c$. 145 million and a population density of $>1,110$ people $/ \mathrm{km}^{2}$ (Badan Pusat Statistik, 2016). Biological endemism is concentrated on the island's volcanic mountains, particularly in the western part where the equatorial climate delivers high levels of rain to the forests that cover the slopes of $\mathrm{c}$. 20 mountains (Whitten et al., 1997). Forest cover in the area declined by c. 40\% during $1988-2000$ and then stabilized at c. 5,200 $\mathrm{km}^{2}$. The remaining forests are highly fragmented and in need of protection (Higginbottom et al., 2019).

The mountains in western Java harbour numerous endemic and Sundaic species (Whitten et al., 1997). The 


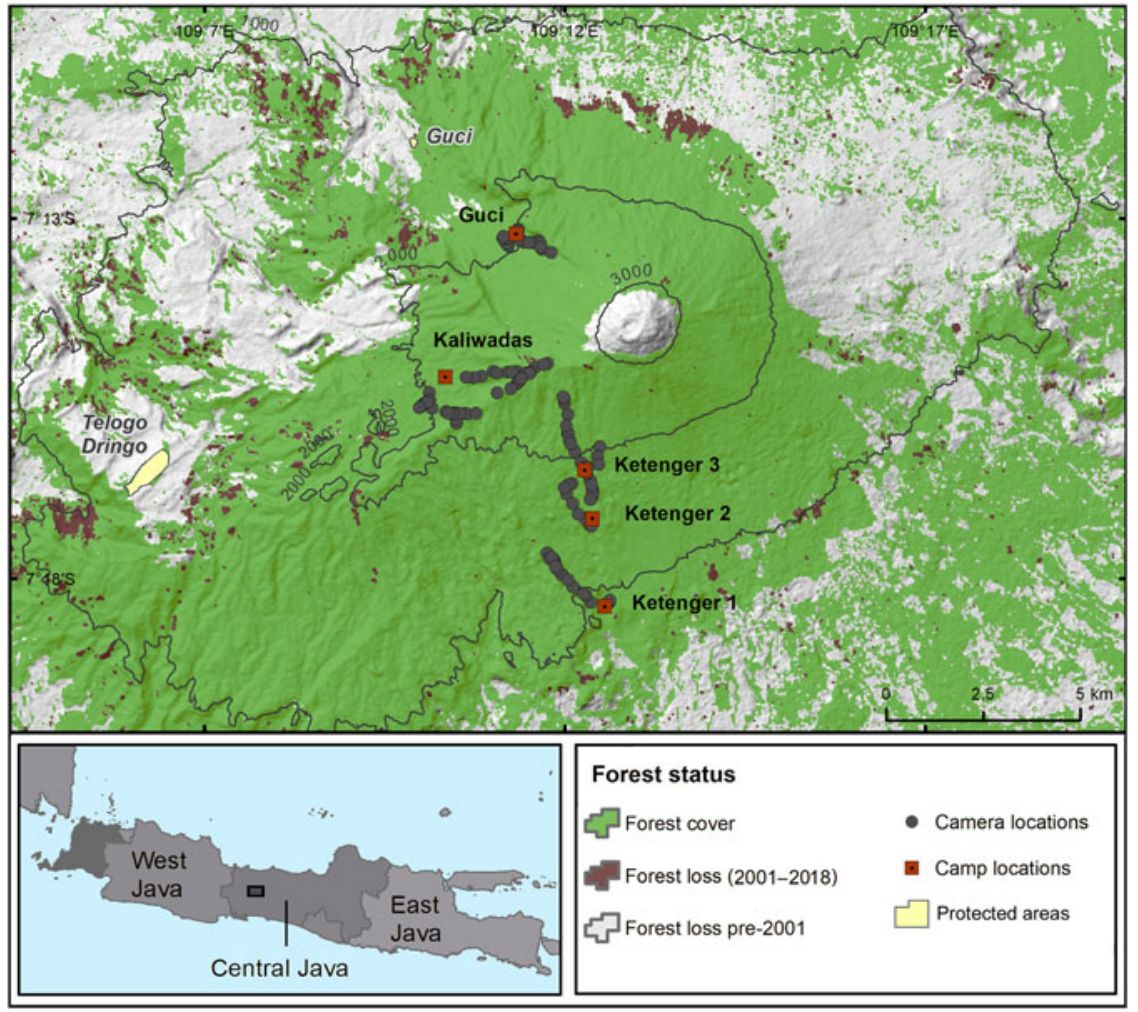

FIG. 1 Gunung Slamet, Central Java, with study sites, camera-trap locations, protected areas, forest cover in 2018 and forest loss since 2001. Camp locations correspond to the survey sites, with transects not further than $2 \mathrm{~km}$ from these points. easternmost of these mountains, Gunung Slamet, in western Central Java province, shares many taxa with the mountains further west but also possesses a degree of endemism of its own, such as a distinctive subspecies of the Javan laughingthrush Garrulax rufifrons slamatensis (Collar \& van Balen, 2013). Its forests, like those in other mountain areas in Central Java, transition from tropical in the west to monsoon in the east (Widhiono, 2015), and comprise lowland, montane and subalpine types (Soemarno \& Girmansyah, 2012). The biological richness of Gunung Slamet was first described during Indonesia's colonial period. Since 2000, there have been studies of ferns (Praptosuwiryo, 2013), termites (Pribadi et al., 2011), butterflies (Widhiono, 2015), bees and wasps (Widhiono et al., 2016), birds (Widodo, 2010, 2012), the Javan surili Presbytis comata (Setiawan et al., 2007), Javan gibbon Hylobates moloch (Setiawan et al., 2012; Wahyuni \& Nasution, 2016) and Javan leopard Panthera pardus melas (Wibisono et al., 2018). In 2012 the Indonesian Institute of Sciences published a compilation of studies on the mountain's geology, climatology and biodiversity (Maryanto et al., 2012).

When Indonesia's protected area system underwent a review in the early $1980 \mathrm{os}, 150 \mathrm{~km}^{2}$ of natural habitat at 1,000-3,418 m altitude on Gunung Slamet were recommended for protection as a nature reserve (MacKinnon, 1982; MacKinnon et al., 1982; Nijman \& Sözer, 1996; Sözer et al., 1997). However, no action was taken on this recommendation and forest areas on the mountain, which serve as hydrological protection forest for five rivers flowing north and five flowing south, are currently managed by the State Forest Management Agency (Perum Perhutani). The absence of formal protection for its biodiversity has left Gunung Slamet threatened by encroachment of human activities (Setiawan et al., 2012). As part of a wider initiative to document the biodiversity of western Java's montane forests and to make recommendations for implementing a protected area status, we undertook field research on Gunung Slamet in 2018, to assess its biological diversity and identify priority conservation areas. Here, we present data on the distribution and relative abundance of key faunal taxa, and on forest cover, forest loss and threats such as bird trapping.

\section{Study area}

Gunung Slamet, an active stratovolcano in Purbalingga Regency in Central Java (Fig. 1), is the second highest mountain on Java, at 3,432 m (Maryanto et al., 2012). It receives an annual rainfall of c. $4,500 \mathrm{~mm}$, which is among the highest precipitation levels in Indonesia. The rainy season is October-May/June, and the dry season July-September. Daytime temperatures are $20-28^{\circ} \mathrm{C}$ (Widhiono, 2015). The volcano last erupted in 2014, and previously in 2009, with some forest burnt as a result. We worked at six study sites on accessible trails leading up to the summit, at altitudes of 970-2,512 m (Table 1, Fig. 1), avoiding the most heavily used tourist trail and the site of a recent forest fire on the 
eastern side of the mountain, and the restricted area surrounding the proposed Baturraden geothermal plant on the western side.

\section{Methods}

\section{Biodiversity surveys}

We carried out fieldwork during September-December 2018, using three survey methods: camera traps, walking transects along trails to record birds, and searches for amphibians, complemented by vegetation surveys along transect lines. We positioned 20 camera traps along trails, c. 150-200 m apart, at locations with signs of activities of terrestrial mammals such as scratch marks, rubs, scats and animal trails (Fig. 1). The camera traps were fastened to trees, c. $0.5 \mathrm{~m}$ above the ground and set to operate continuously for 3 days at each site, recording photographs and video footage, for a total of 360 camera-days. Our camera setup did not target small mammals such as rodents and bats. To estimate bird encounter rates, we walked a mean of 10 transects of variable length and duration along trails (including those where we set up camera traps) at all sites apart from Ketenger 1, noting bird species seen and/or heard, number of individuals per group and time of day. We generally walked transects between 6.00 and 9.00, at a speed of c. $1 \mathrm{~km} / \mathrm{h}$. We surveyed for amphibians along streams and in wetter areas surrounding the camp and trails for c. 3 hours after dusk for 3 days per site, recording amphibian presence and habitat type with photographs. We surveyed vegetation in plots with a radius of $10 \mathrm{~m}$, every $200 \mathrm{~m}$ along transect lines. At each site we measured the girth at breast height of the three largest trees, and recorded presence of palms and other indicator species, ground cover, and evidence of human disturbance such as cut mist-nets, tree stumps and hunter/trapper camps.

We aggregated bird encounter rates at each site, as mean number of groups per hour. Species not encountered during transect walks, but that appeared in the complete species list for all sites, were included as zero counts. We estimated bird species richness at each site using the Chao 1 estimator over species presence on transects (Chiu et al., 2014). We tested for differences in encounter rate between sites, and between threatened and non-threatened species, using KruskalWallis and Wilcoxon two sample tests, respectively, in $R$ 4.o.o (R Core Team, 2020). To identify mammals from the camera-trap captures, several authors provided preliminary identifications that were then compared. In cases of discrepancy we consulted experts, and we omitted the records if uncertainty remained about species identification $(6 \%$ of images of mammals). We estimated mammal encounter rates from camera-trap data by calculating the proportion of cameras with records of each species of the total number of cameras that had recorded mammal species, thus avoiding some of the issues associated with identifying independent observation events (Wearn \& Glover-Kapfer, 2017).

\section{Identifying priority areas for conservation}

To prioritize areas of particular significance for the protection of biodiversity, we built species distribution models for species of conservation concern, using an approach suitable for small numbers of occurrence points (Breiner et al., 2015). For birds categorized as threatened or near threatened on the IUCN Red List (i.e. categories Critically Endangered, Endangered, Vulnerable, Near Threatened), individual models were built for species with $>10$ records and then summed to produce a generalized habitat suitability map. For mammals, all species of conservation concern (globally threatened, on Indonesia's national protection list, or endemic; Ministry of Environment and Forestry, 2018b) were modelled together as a single group. All species have different ecological niches, but as the objective was to prioritize areas for conservation more broadly, we interpreted the model results to show those areas of habitat most critical for mammals of conservation concern (there is evidence to suggest threatened species can be effective surrogates for establishing conservation priorities; Tognelli, 2005; Drummond et al., 2010). Predictors, at $30 \mathrm{~m}$ resolution, were topographic (elevation, slope, roughness and topographic wetness index) and habitat-related (percentage of tree cover in 2018, and normalized difference vegetation index, NDVI). Elevation and derived topographic metrics were calculated from the ASTER digital elevation model (Aster DEM, 2001). The topographic wetness index provides an indication of upstream flow accumulation and is correlated with soil characteristics (Quinn et al., 1995; Raduła et al., 2018); the index was created with the dynatopmodel package in $R$ (Metcalfe et al., 2018). We extracted tree cover from Hansen et al. (2013), and NDVI from two merged Landsat 8 images (taken on 22 October and 7 November 2019) with almost no cloud cover (USGS, 2019).

We used species occurrence points from transect surveys, occasional sightings and camera traps. Additional points were taken from a survey by SvB on west Gunung Slamet in June 2018 as part of an environmental impact assessment in the area of a proposed, but presently abandoned, geothermal plant. To avoid sampling bias, we restricted random background points to within a $2.5 \mathrm{~km}$ radius of presence points (Kramer-Schadt et al., 2013; Merow et al., 2013), given a lack of other biological records of similar taxa that would have allowed us to implement more complex methods (Phillips et al., 2009). We followed modelling methods described by Breiner et al. (2015). For each species or group, we made ensembles of all combinations of bivariate models using Maxent 3.4.1 (Phillips \& Dudík, 2008), with each 
TABLE 1 Topography and habitat characteristics at six study sites on Gunung Slamet, Central Java, with survey effort and species richness for birds and mammals.

\begin{tabular}{|c|c|c|c|c|c|c|}
\hline & Ketenger 1 & Ketenger 2 & Ketenger 3 & Kaliwadas 1 & Kaliwadas 2 & Guci \\
\hline \multicolumn{7}{|l|}{ Topography } \\
\hline Altitude range $(\mathrm{m})$ & $730-1,250$ & $1,265-1,885$ & $1,825-2,510$ & $2,060-2,470$ & $1,975-2,265$ & $1,885-2,250$ \\
\hline \multicolumn{7}{|l|}{ Habitat/disturbance } \\
\hline Mean tree girth $(\mathrm{cm})$ (range) & $\begin{array}{l}125 \\
(60-320)\end{array}$ & $\begin{array}{l}158 \\
(22-416)\end{array}$ & $\begin{array}{l}178 \\
(53-402)\end{array}$ & $\begin{array}{l}206 \\
(67-490)\end{array}$ & $\begin{array}{l}248 \\
(117-486)\end{array}$ & $\begin{array}{l}166 \\
(70-579)\end{array}$ \\
\hline Presence of secondary trails (\% of plots) & 50.0 & 43.8 & 31.3 & 16.7 & 75.0 & 85.7 \\
\hline Presence of cut stumps (\% of plots) & 8.3 & 37.5 & 37.5 & 33.3 & 0.0 & 71.4 \\
\hline \multicolumn{7}{|l|}{ Birds (transects) } \\
\hline Transect effort: distance $(\mathrm{km})$; time $(\mathrm{h})$ & & $25.4 ; 82.0$ & $14.2 ; 42.8$ & $33.1 ; 37.9$ & $19.5 ; 31.6$ & $10.6 ; 24.6$ \\
\hline Species richness (globally threatened) & & $66(5)$ & $52(4)$ & $67(2)$ & $45(4)$ & $56(5)$ \\
\hline Rarified richness Chao estimator \pm SE & & $79 \pm 9.0$ & $55 \pm 3.2$ & $75 \pm 5.5$ & $50 \pm 4.2$ & $66 \pm 7.5$ \\
\hline \multicolumn{7}{|l|}{ Mammals (camera traps) } \\
\hline $\begin{array}{l}\text { Camera-trap effort (h) (\% of cameras } \\
\text { with mammal records) }\end{array}$ & $1,421(15)$ & $2,858(55)$ & $1,247(43)$ & $1,766(32)$ & $1,275(79)$ & $1,790(53)$ \\
\hline Richness (globally threatened) & $2(0)$ & $7(1)$ & $5(0)$ & $6(1)$ & $9(1)$ & $5(0)$ \\
\hline
\end{tabular}

individual model weighted by Somer's D, a rescaled area under the receiver operating characteristic curve (AUC) that gives prominence to higher values. To validate the models, we implemented 10 runs of 2-fold cross validation, obtaining an overall mean AUC for each species. The mean AUC of the 10 runs of each bivariate model was then used to weight a final full ensemble model of all bivariate combinations using all the occurrence points. We created models using the dismo, ecospat and raster packages in $R$ (Hijmans et al., 2016; Di Cola et al., 2017; Hijmans, 2019).

\section{Forest loss, threats and conservation status}

We calculated forest loss during 2001-2018 using a global forest cover dataset based on $30 \mathrm{~m}$ resolution Landsat images (Hansen et al., 2013). For the Tropical domain, this classification obtained an overall accuracy of $99.5 \%$ and a precision of $87.0 \%$ for forest loss (Hansen et al., 2013). We performed the analysis on the area surrounding Gunung Slamet at altitudes $>500 \mathrm{~m}$, per $500 \mathrm{~m}$ altitudinal band, per year.

To examine human use of forest trails, we counted and categorized people recorded by camera traps as either recreational users (e.g. hikers wearing trainers and backpacks) or local people believed to be exploiting forest resources (e.g. wearing flip-flops and synthetic sacking bags). We excluded from these counts members of the research team recorded by cameras. We used a $G$ test (Zar, 1999) to evaluate whether certain sites were used more or less frequently by recreational or resource users. We obtained additional data on the use of forest resources and bird trapping from a bird market survey in the town of Purwokerto ( $20 \mathrm{~km}$ from the summit of Gunung Slamet), and through informal conversations with members of the local community, including our guides on the field trips.

\section{Results}

\section{Biodiversity surveys}

We observed 99 bird species on the transect walks, of which 13 are of conservation concern globally (two Critically Endangered, one Endangered, four Vulnerable and six Near Threatened; Supplementary Table 1a), and 21 are included in Indonesia's national protection list (Ministry of Environment and Forestry, 2018b). Twenty-five species were restricted to the Java and Bali Forest Endemic Bird Area (Stattersfield et al., 1998). Species richness varied from 45 species at Kaliwadas 2 to 67 at Kaliwadas 1, both on the north side (Table 1). Estimated species richness was highest at Ketenger 2 with $79 \pm$ SE 9 species (Table 1 ). In terms of species composition, sites on the same flanks (north or south) and geographically closest were most similar. However, when we used encounter rates to gauge similarity between sites, the highest site on the south side, Ketenger 3, was more similar to two other sites on the north side than to its nearest site, Ketenger 2 (Fig. 2). Encounter rates per site were low for species at the upper end of their altitudinal distribution (e.g. the blue whistling thrush Myophonus caeruleus, 0.006 groups/h), and highest for the Javan tesia Tesia superciliaris (3.75, 4.58 and 5.66 groups/h at Kaliwadas 2, Kaliwadas 1 and Guci, respectively). Median encounter rates were significantly lower at Ketenger 2 compared to three other sites: Guci, Kaliwadas 1 and Kaliwadas 2 (Kruskal-Wallis; $\chi^{2}=15.9, \mathrm{df}=4$, $\mathrm{P}=0.003$ ), and significantly lower for species of conservation concern than others (Wilcoxon test; $W=2924$, $\mathrm{P}=0.010$ ). Maximum encounter rates for threatened or near threatened species did not coincide at the same sites, with all sites having a maximum value for at least one 


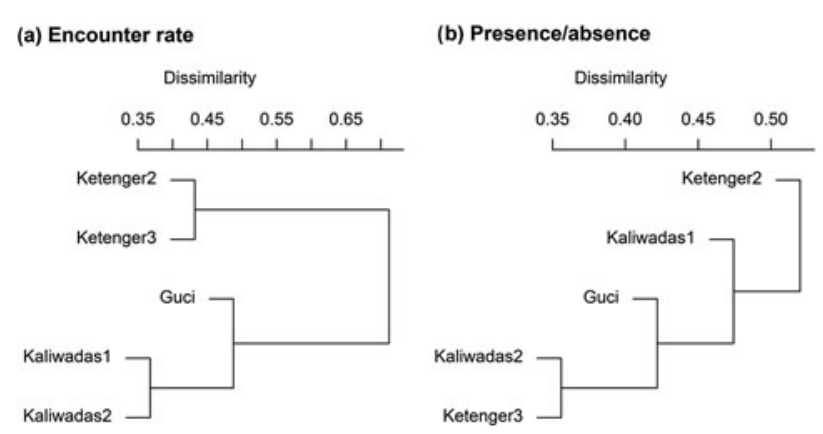

FIG. 2 Similarity between sites using (a) encounter rates, and (b) species composition. Ketenger 1 did not have data for encounter rates (see text).

species. Threatened species encountered on both sides of the mountain were the endemic subspecies of the Javan laughingthrush G. rufifrons slamatensis, with a maximum encounter rate of $0.43 \pm \mathrm{SE} 0.08$ groups/h, Javan cochoa Cochoa azurea (0.48 $\pm \mathrm{SE}$ 0.10 groups/h), Javan trogon Apalharpactes reinwardtii $(0.20 \pm \mathrm{SE} \quad 0.08)$ and Javan hawk-eagle Nisaetus bartelsi ( $0.15 \pm \mathrm{SE} 0.05$ groups/h). For security reasons we are not reporting the exact locations where we encountered threatened species (Collar et al., 2017).

Thirteen mammal species were captured by 51 of 112 camera traps (total effort $=10,358 \mathrm{~h}$; Table 1, Supplementary Table 1b). A further two species, the Vulnerable Javan lutung Trachypithecus auratus and Endangered Javan gibbon Hylobates moloch, were only recorded on transect walks. Of the 15 mammal species recorded, five are globally threatened (one Critically Endangered, two Endangered, two Vulnerable) and nine are on the Indonesian protection list (Ministry of Environment and Forestry, 2018b; Supplementary Table 1b). Of the mammals known to occur on Gunung Slamet, we failed to record the Javan mongoose Herpestes javanica, wild boar Sus scrofa, dhole Cuon alpinus (Maryanto et al., 2012) and mountain weasel Mustela lutreolina (Meiri et al., 2007). However, we recorded three species not previously known to occur there: the Sunda porcupine Hystrix javanica, Sunda pangolin Manis javanica and banded linsang Prionodon linsang. The maximum number of species recorded by a single camera trap was four, and $>70 \%$ of camera traps with mammal sightings recorded just one species. Mammal species richness per site was 5-9, with the maximum at Kaliwadas 2 on the north side (Table 1). Threatened species caught on camera traps were the Javan leopard Panthera pardus melas, Sunda pangolin and Javan surili. The Javan stink badger Mydaus javanensis, Javan treeshrew Tupaia javanica and three-striped ground squirrel Lariscus insignis were recorded at four sites each, with the Javan stink badger the most frequently recorded species (11 cameras), followed by the Javan leopard (10) and Asian palm civet Paradoxurus hermaphroditus (10). Encounter rates (proportion of cameras that recorded a particular species) for mammals ranged from 0.04 for the Sunda porcupine to 0.22 for the Javan stink badger (Supplementary Table ib).
We found 17 species of reptiles and amphibians, all of which are categorized as Least Concern (IUCN, 2019), including two endemic species, the pearly tree frog Nyctixalus margaritifer and Java flying frog Rhacophorus margaritifer (Supplementary Table 1c).

\section{Priority zones for birds and mammals on Gunung Slamet}

We included a total of 154 records of five bird species, and 74 records of 10 mammal species in the species distribution models (Supplementary Table 2). Evaluation results for the ensembles of small models were generally good, with the overall mean AUC of all species $0.93 \pm \mathrm{SE} 0.005$. Individual mean AUC values of the 10 runs ranged from $0.88 \pm \mathrm{SE} 0.012$ to $0.95 \pm \mathrm{SE} 0.004$. The summed species distribution model for birds showed broad congruence with the model for mammals, with most suitable habitat consisting of a broad band of forest around the whole mountain at an altitude $>1,000 \mathrm{~m}$, but covering a larger area on the western slopes. High values of habitat suitability for birds extended to slightly lower altitudes than for mammals, especially on the southern slopes at 1,000-2,000 m (Fig. 3).

\section{Forest loss and other threats}

In total, $13.7 \mathrm{~km}^{2}$ of forest $(1.7 \%$ of total) were lost from Gunung Slamet during 2001-2018, with most loss occurring below 2,000 $\mathrm{m}$ (Figs $1 \& 4$ ). A large, continuous block of forest covers Gunung Slamet at higher altitudes and reaches lower elevations on the south and south-east slopes (Fig. 1). At lower altitudes, the forest is severely fragmented. A core area, over c. $800 \mathrm{~m}$ in elevation, contains $288 \mathrm{~km}^{2}$ of continuous forest. The presence of large trees with girths $>4 \mathrm{~m}$ indicated high quality of forest habitat, but at all but one site we observed cut stumps in $>30 \%$ of vegetation plots (Table 1).

People (excluding the research team) were recorded by $63 \%$ of cameras. Potential resource users were recorded by $>50 \%$ of cameras, and recreational users by $22 \%$. Recreational and resource users followed similar trails, but were recorded less at the Guci site. However, there was no significant association between site and user type ( $G$ test; $\mathrm{G}=9.11, \mathrm{df}=5, \mathrm{P}=0.105)$. An additional trail on the eastern side of Gunung Slamet, not surveyed here, provides access for large numbers of visitors (Mittermeier et al., 2014).

Several local people, including our guides and porters, admitted to trapping birds on Gunung Slamet, although all did so opportunistically rather than as their main source of income. The main trapping techniques were snares, stick traps and mist-nets, sometimes with tape lures or by stringing a snake from a tree so that its movement attracts birds. Guides informed us that trappers could use the extensive network of trails to access most, if not all, of the mountain's 


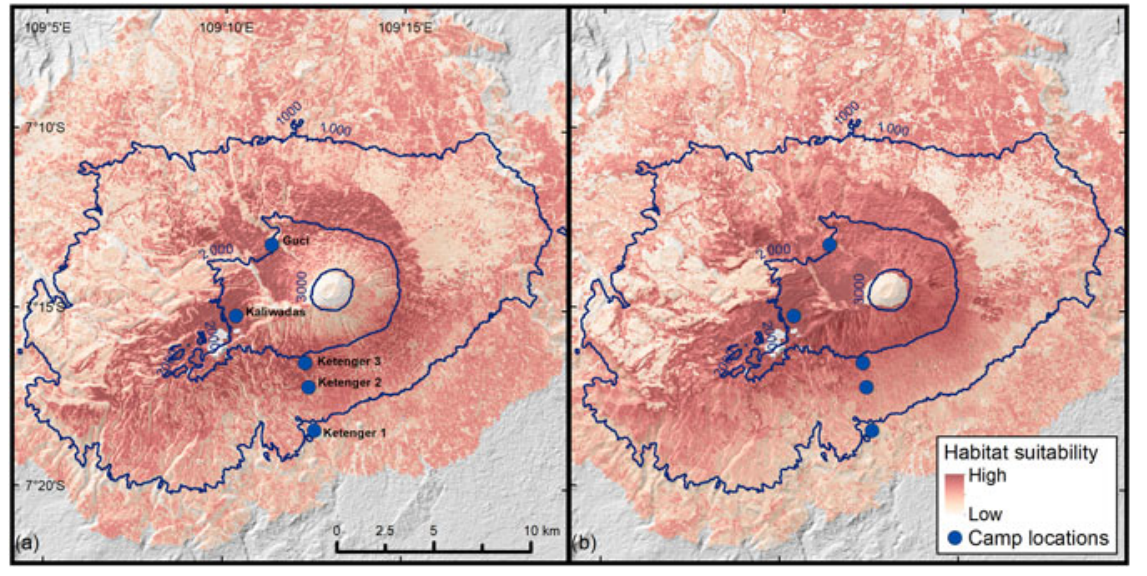

FIG. 3 Distribution models for (a) globally threatened birds $(n=5)$ and (b) mammals of conservation concern $(\mathrm{n}=10)$.

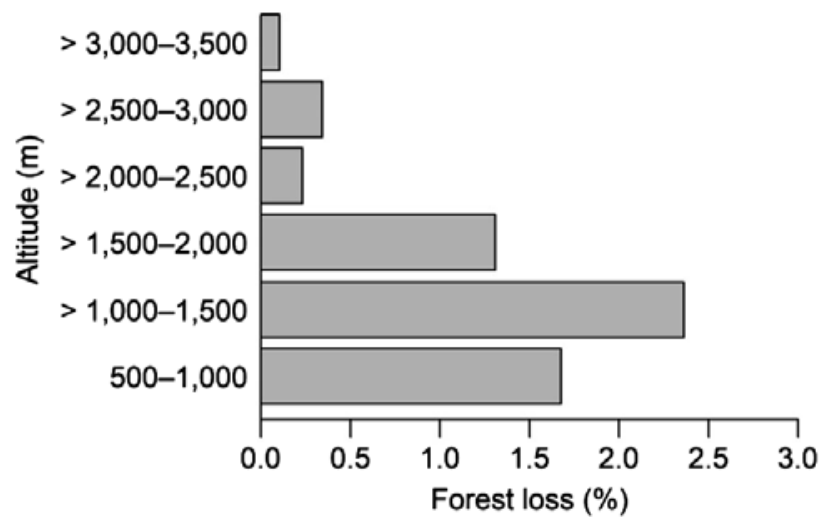

FIG. 4 Forest loss across Gunung Slamet during 2001-2018, per altitudinal band as a percentage of total band area.

forest areas, except those used by large numbers of tourists. At $40 \%$ of vegetation plots across all sites, the nearest main trail had a secondary trail leading from it (Table 1). According to local people, access to the restricted area around the geothermal site was more difficult, but still possible for bird trappers. On 6 September 2018 at the live bird market in Purworkerto, we observed the indigo flycatcher Eumyias indigo, mountain warbler Phylloscopus trivirgatus, hill blue-flycatcher Cyornis banyumas and several other species that reportedly had been caught locally on the mountain.

\section{Discussion}

\section{The biological importance of Gunung Slamet}

Gunung Slamet is a stronghold of Java's unique montane fauna. During 6 weeks of fieldwork, we recorded 13 bird species of global conservation concern, 28 birds with restricted ranges (within the Java and Bali Forest Endemic Bird Area), five threatened mammal species, six endemic mammals and two endemic frogs. Thirty of these species are included in the Indonesian government protection list (Ministry of
Environment and Forestry, 2018b) and four species legislated as priorities for conservation strategies: the Javan hawk-eagle (very high priority) and Javan leopard, Javan gibbon and Javan surili (high priority; Ministry of Forestry, 2008).

The presence, and in some cases abundance, of certain species is noteworthy. We observed G. rufifrons slamatensis, the subspecies of the Javan laughingthrush endemic to Gunung Slamet, at several sites on the mountain. It had not been recorded in the wild since 1925 (Collar \& van Balen, 2013; Mittermeier et al., 2014), but was present in bird markets (Nijman et al., 2020; Species 360 ZIMS, 2020). The Javan hawk-eagle was widespread despite increasing pressure from trappers (Eaton et al., 2015), as were the Javan cochoa and Javan trogon. The latter, previously known only from West Java (Collar \& van Balen, 2002) has extended its range considerably, with Gunung Slamet as its new easternmost limit. The Javan flameback Chrysocolaptes strictus has also rarely been recorded in Central Java (Mees, 1996), and ours appears to be the first confirmed record there of the Javan scops-owl Otus angelinae (König \& Weick, 2008). The presence of the Sunda grasshopper warbler Locustella montis on Gunung Slamet suggests another range expansion, c. $100 \mathrm{~km}$ to the west of the species' previously known range (Rozendaal, 1989). These records highlight the key position of Gunung Slamet as a meeting point of the eastern and western Javan avifaunas. Notable absences from our surveys, and also from a 2013 survey (Mittermeier et al., 2014), were the Javan green magpie Cissa thalassina, known from a single record on Gunung Slamet from 1917 (van Balen et al., 2013), and Javan oriole Oriolus cruentus. The Javan green magpie was probably not recorded as a result of considerable trapping pressure on this species (van Balen et al., 2013; Nijman et al., 2017). The oriole, however, although generally inconspicuous and easily overlooked, was recorded by our survey team at four sites on two other mountains in West Java during the same field season (A.R. Junaid \& G.C. Aprianto, unpubl. data). Other species 
that were unexpectedly rare included the white-bellied fantail Rhipidura euryura and chestnut-backed scimitarbabbler Pomatorhinus montanus, possibly also indicative of heavy trapping pressure.

Amongst the threatened mammals, the Javan gibbon, Javan surili and Javan leopard were relatively common. We expected the mountain to harbour significant populations of these species, given that $>28 \mathrm{o} \mathrm{km}^{2}$ of forest remain, with likely population densities in West and Central Java of 1.70 and 5.96 and individuals $/ \mathrm{km}^{2}$ for the Javan gibbon (Setiawan et al., 2012) and Javan surili (Setiawan et al., 2010), respectively, and 10-12 individuals $/ 100 \mathrm{~km}^{2}$ for the Javan leopard (Rahman et al., 2018). By contrast, the heavily trapped Sunda pangolin was recorded only once, although pangolins require higher camera-trap effort or specific targeting to achieve higher detections (Khwaja et al., 2019).

\section{Threats and opportunities on Gunung Slamet}

Forests on the lower slopes of Gunung Slamet are fragmented, with agriculture encroaching up to higher altitudes on the northern side. Although forest loss is less at higher elevations, $>160 \mathrm{~km}^{2}$ of montane forest are estimated to have been lost during 2000-2012 across Java (Margono et al., 2014). Nevertheless, the forest on Gunung Slamet's upper slopes is still relatively intact, with large trees persisting at the study sites despite evidence of small-scale logging. This forest forms a $280 \mathrm{~km}^{2}$ continuous block above c. $800 \mathrm{~m}$ altitude, and our species distribution models indicate this offers the most suitable habitat for threatened species.

Bird trappers operate via an extensive network of trails across the mountain. There are no quotas for the capture of wild birds in Central Java, and commercial harvest is illegal (Ministry of Environment and Forestry, 2018a, 2020). Camera-trap footage revealed significant traffic of resource users in the forest. Given the lack of formal protection and the access provided by the trail network, trapping pressure is probably high and persistent (Marshall et al., 2020). Eleven specimens of $G$. rufifrons slamatensis were recently acquired by breeding centres in Indonesia from markets, five in 2017, and six in 2018 (Species 360 ZIMS, 2020). Hikers also use the 3-4 main trails to the mountain's summit, and the recreational park and waterfall at Ketenger on the lower slopes. Their presence may benefit the mountain's wildlife (Hakim et al., 2018), deterring trappers and providing income to local guides, many of whom nevertheless trap birds to supplement their income. However, Gunung Slamet is one of the main destinations for mountain hiking in Central Java, with thousands of people ascending the summit each year, and further regulation beyond ticketing may be required (Republika, 2010).

Although we believe our findings are comprehensive considering the methods used, more species would probably be recorded with longer surveys across other seasons. We conducted our surveys during the dry season, for logistical reasons, and species detectability may vary between seasons. We did not cover the westernmost slopes of Gunung Slamet, for logistical reasons and because of access restrictions around the geothermal site. These restrictions may inhibit trappers, but if construction of the plant is abandoned, which appears likely, the new road to the site will facilitate access for resource users.

\section{Improving the protection status of Gunung Slamet}

The current status of Gunung Slamet is a so-called protection forest (hutan lindung), managed by Perum Perhutani, the state forest enterprise (Supplementary Table 3). Protection forests are managed to regulate water systems, prevent flooding, control erosion, and maintain soil fertility, but are not classified as protected areas under Indonesian government regulations (CIFOR, 2003). Two small protected areas are present at Guci ( $2 \mathrm{ha}$ ) and Telogo Dringo (48.5 ha), on the north and west flanks, respectively, but these are far from the main blocks of montane forest (UNEP-WCMC \& IUCN, 2019; Fig. 1, Supplementary Table 3). However, our findings and previous studies highlight the significance of the mountain for biodiversity (Setiawan et al., 2012), including as a key site for the Javan hawk-eagle (Sözer et al., 1997). We therefore recommend the designation of a higher protection status for Gunung Slamet, in line with regional priorities for forest conservation (Sodhi et al., 2010).

One option is to designate Gunung Slamet as a protected area within IUCN categories I-IV, under national management. A Nature Reserve under Indonesian legislation would confer strict protection (Basjarudin, 1971), and our findings suggest that the mountain's levels of biological diversity and endemism meet the criteria for this designation (Indonesian Government, 2011). However, both resource and recreational use could be in conflict with this designation. Several villages in the districts of Tegal, Pemalang, Pubalingga, Banjaran and Banyumas source water from Gunung Slamet (Gunawan, 2012). A more accommodating protected area category is National Park (Indonesian Government, 2011), which has the objective of protecting life-support systems and species diversity while also allowing the sustainable use of natural resources. A third option is the designation of Essential Ecosystem within High Conservation Areas, managed by Perum Perhutani locally, including the identification of priority areas for birds and mammals, such as those areas highlighted by the species distribution models (Ditjen KSDAE, 2018). Essential Ecosystems aim to protect biodiversity and maintain ecosystem services outside conservation areas (Direktorat Bina Pengelolaan Ekosistem Esensia, 2019), but have yet to be fully regulated by the Ministry of Environment and Forestry (Supplementary Table 3). 
Gunung Slamet is a vital refuge for montane biodiversity in Central Java and therefore should receive greater protection in the form of one of these three designations.

Acknowledgements We thank the student volunteers, Arya and Hafiz, and our local guides, for their help with fieldwork; Faris Muladi and Hannah Khwaja for help with identification of mammal images; the Ministry of Environment and Forestry and Perum Perhutani for facilitating research and fieldwork; Rainforest Trust, Chester Zoo and the EAZA Silent Forest Campaign for funding; and Vincent Nijman and an anonymous reviewer for their constructive comments. We dedicate this paper to the memory of Tony Whitten.

Author contributions Field surveys: ARJ, assisted by GCA, RS, FK, $\mathrm{CD}$, SJM; support with bird identification: BvB; data analysis: $\mathrm{CD}$; writing: CD, NJC, SJM; editing: all authors.

\section{Conflicts of interest None.}

Ethical standards This research complied with the Oryx guidelines on ethical standards. Fieldwork did not involve collection of any specimens. No ethical standards for camera trapping currently exist in Indonesia, however, all images have been stored securely and are treated as strictly confidential. The project complies with ethical standards of Manchester Metropolitan University and was carried out with permissions obtained from relevant authorities in Indonesia (Memorandum of Understanding with Kementerian Lingkungan Hidup Dan Kehutanan: S. 37/KSDAE/PIKA/ILSA.0/1/2018).

\section{References}

Aster DEM (2001) ASTER DEM Product. NASA EOSDIS Land Processes DAAC, Sioux Falls, USA. doi.org/10.5067/ASTER/ AST14DEM.oo3 [accessed 23 March 2021].

Badan Pusat Statistik (2016) Profil Penduduk Indonesia Hasil Supas. Badan Pusat Statistik, Jakarta, Indonesia.

BASJARUdin, H. (1971) Nature reserves and national parks in Indonesia-present situation and problems. IUCN Eleventh Technical Meeting-Paper and Proceedings, 18, 27-33.

Bradshaw, C.J.A., Sodhi, N.S. \& Brook, B.W. (2009) Tropical turmoil: a biodiversity tragedy in progress. Frontiers in Ecology and the Environment, 7, 79-87.

Breiner, F.T., Guisan, A., Bergamini, A. \& Nobis, M.P. (2015) Overcoming limitations of modelling rare species by using ensembles of small models. Methods in Ecology and Evolution, 6, 1210-1218.

Ceballos, G., Ehrlich, P.R. \& Dirzo, R. (2017) Biological annihilation via the ongoing Sixth Mass Extinction signaled by vertebrate population losses and declines. The Proceedings of the National Academy of Sciences, 114, E6089-E6096.

Chandra, A. \& Idrisova, A. (2011) Convention on biological diversity: a review of national challenges and opportunities for implementation. Biodiversity and Conservation, 20, 3295-3316.

Chape, S., Harrison, J., Spalding, M. \& Lysenko, I. (2005) Measuring the extent and effectiveness of protected areas as an indicator for meeting global biodiversity targets. Philosophical Transactions of the Royal Society B, 360, 443-455.

Chiu, C.-H., Wang, Y.-T., Walther, B.A. \& Chao, A. (2014) An improved nonparametric lower bound of species richness via a modified Good-Turing frequency formula. Biometrics, 70, 671-682.

Cifor (Centre for International Forestry Research) (2003) Klasifikasi Kawasan Konservasi Indonesia. Warta kebijakan 11. Centre for International Forestry Research, Bogor, Indonesia.
Collar, N. \& van Balen, S. (2002) The Blue-tailed Trogon Harpactes (Apalharpactes) reinwardtii: species limits and conservation status. Forktail, 18, 121-125.

Collar, N.J. \& van Balen, S. (2013) Notes for the conservation of the rufous-fronted laughingthrush Garrulax rufifrons. Forktail, 29, 15-18.

Collar, N., Eaton, J. \& Sykes, B. (2017) Guest editorial: conservation and the redaction of locality data. BirdingASIA, 28, 3-4.

Di Cola, V., Broennimann, O., Petitpierre, B., Breiner, F.T., D'Amen, M., Randin, C. et al. (2017) Ecospat: an $R$ package to support spatial analyses and modeling of species niches and distributions. Ecography, 40, 774-787.

Direktorat Bina Pengelolaan Ekosistem Esensia (2019) Laporan kinerja Direktorat Bina pengelolaan Ekosistem Esensial tahun 2018. Kementrian Lingkungan Hidup dan Kehutanan, Indonesia.

Ditjen KSDAE (2018) Rancangan peraturan Menteri LHK tentang pedoman perlindungan Kawasan Ekosistem Esensial. Kementrian Lingkungan Hidup dan Kehutanan, Indonesia.

Drummond, S.P., Wilson, K.A., Meijaard, E., Watts, M., Dennis, R., Christy, L. \& Possingham, H.P. (2010) Influence of a threatened-species focus on conservation planning. Conservation Biology, 24, 441-449.

Eaton, J.A., Shepherd, C.R., Rheindt, F.E., Harris, J.B.C., van Balen, S.(B.), Wilcove, D.S. \& Collar, N.J. (2015) Trade-driven extinctions and near-extinctions of avian taxa in Sundaic Indonesia. Forktail, 31, 1-12.

Gunawan, D. (2012) Kajian Hidro Klimatologi Wilayah Gunung Slamet Jawa Tengah. In Ekologi Gunung Slamet (eds I. Maryanto, M. Noerdjito \& T. Partomihardjo), pp. 31-40. LIPI Press, Jakarta, Indonesia.

Hakim, L., Rahardi, B. \& Rachmansyah, A. (2018) Checklist of flora along tourist trails to Mt. Lamongan, East Java (Indonesia): misconception of restoration and ecotourism programs in mountain region? Journal of Degraded and Mining Lands Management, 5, 1299-1305.

Hansen, M.C., Potapov, P.V., Moore, R., Hancher, M., Turubanova, S.A., Tyukavina, A. et al. (2013) High-resolution global maps of 21st-century forest cover change. Science, 342, 850-853.

Harrop, S.R. \& Pritchard, D.J. (2011) A hard instrument goes soft: the implications of the Convention on Biological Diversity's current trajectory. Global Environmental Change, 21, 474-48o.

Higginbottom, T.P., Collar, N.J., Symeonakis, E. \& Marsden, S.J. (2019) Deforestation dynamics in an endemic-rich mountain system: conservation successes and challenges in West Java 1990-2015. Biological Conservation, 229, 152-159.

Hijmans, R.J. (2019) Raster: Geographic data analysis and modeling. $\mathrm{R}$ package. rdrr.io/cran/raster [accessed 23 March 2021].

Hijmans, R.J., Phillips, S., Leathwick, J. \& Elith, J. (2016) Dismo: Species distribution modeling. R package. cran.r-project.org/web/ packages/dismo/dismo.pdf [accessed 23 March 2021].

Indonesian Government (2011) Government Regulation No. 28 of 2011 Concerning Management of Nature Reserve Areas and Nature Conservation Areas. Jakarta, Indonesia.

IUCN (2019) IUCN Red List of Threatened Species. Version 2019-2. iucnredlist.org [accessed 23 March 2021].

Jenkins, C.N. \& Joppa, L. (2009) Expansion of the global terrestrial protected area system. Biological Conservation, 142, 2166-2174.

Jones, K.R., Venter, O., Fuller, R.A., Allan, J.R., Maxwell, S.L., Negret, P.J. \& WAtson, J.E.M. (2018) One-third of global protected land is under intense human pressure. Science, 360, 788-791.

Khwaja, H., Buchan, C., Wearn, O.R., BahaA-El-Din, L., Bantlin, D., Bernard, H. et al. (2019) Pangolins in global camera trap data: implications for ecological monitoring. Global Ecology and Conservation, 20, eoo769. 
König, C. \& WeICK, F. (2008) Owls of the World. 2nd edition. Christopher Helm, London, UK.

Kramer-Schadt, S., Niedballa, J., Pilgrim, J.D., Schröder, B., Lindenborn, J., Reinfelder, V. et al. (2013) The importance of correcting for sampling bias in Maxent species distribution models. Diversity and Distributions, 19, 1366-1379.

Le Saout, S., Hoffmann, M., Shi, Y., Hughes, A., Bernard, C., Brooks, T.M. et al. (2013) Protected areas and effective biodiversity conservation. Science, 342, 803-805.

MacKinnon, J. (1982) National Conservation Plan for Indonesia. Vol. 1: Introduction, Evaluation, Methods and Overview of National Nature Richness. National Parks Development Project of the FAO, Bogor, Indonesia.

MacKinnon, J., Smiet, A.C. \& Artha, M.B. (1982) National Conservation Plan for Indonesia. Vol. 3: Java and Bali. National Parks Development Project of the FAO, Bogor, Indonesia.

Mallari, N.A.D., Collar, N.J., McGowan, P.J.K. \& Marsden, S.J. (2016) Philippine protected areas are not meeting the biodiversity coverage and management effectiveness requirements of Aichi Target 11. Ambio, 45, 313-322.

Margono, B.A., Potapov, P.V., Turubanova, S., Stolle, F. \& Hansen, M.C. (2014) Primary forest cover loss in Indonesia over 2000-2012. Nature Climate Change, 4, 730-735.

Marshall, H., Collar, N.J., Lees, A.C., Moss, A., Yuda, P. \& MARSDEN, S.J. (2020) Spatio-temporal dynamics of consumer demand driving the Asian Songbird Crisis. Biological Conservation, $241,108237$.

Maryanto, I., Noerdjito, M. \& Partomihardjo, T. (2012) Ekologi Gunung Slamet-Geologi, Klimatologi, Biodiversitas dan Dinamika Sosial. Lembaga Ilmu Pengetahuan Indonesia (LIPI), Jakarta, Indonesia.

Mees, G.F. (1996) Geographic variation in birds of Java. Publications of the Nuttall Ornithological Club, 26, 1-119.

Meiri, S., Duckworth, J.W. \& Meijaard, E. (2007) Biogeography of Indonesian Mountain Weasel Mustela lutreolina and a newly discovered specimen. Small Carnivore Conservation, 37, 1-5.

Merow, C., Smith, M.J. \& Silander, J.A. (2013) A practical guide to MaxEnt for modeling species' distributions: what it does, and why inputs and settings matter. Ecography, 36, 1058-1069.

Metcalfe, P., Beven, K. \& Freer, J. (2018) dynatopmodel: Implementation of the Dynamic TOPMODEL Hydrological Model. cran.r-project.org/web/packages/dynatopmodel/index.html [accessed 23 March 2021].

Ministry of Environment and Forestry (2018a) Kuota Pengambilan Tumbuhan Alam Dan Penangkapan Satwa LiarPeriode Tahun 2018. Direktorat Jenderal Konservasi Sumber Daya Alam Dan Ekosistem; Direktorat Konservasi Keanekaragaman Hayati, Jakarta, Indonesia.

Ministry of Environment and Forestry (2018b) Peraturan menteri lingkungan hidup dan kehutanan, Republik Indonesia, Nomor P.20/Menlhk/Setjen/Kum.1/6/2018 tentang jenis tumbuhan dan satwa yang dilindungi. Jakarta, Indonesia.

Ministry of Environment and Forestry (2020) Kuota Pengambilan Tumbuhan Alam Dan Penangkapan Satwa LiarPeriode Tahun 2020. Direktorat Jenderal Konservasi Sumber Daya Alam Dan Ekosistem; Direktorat Konservasi Keanekaragaman Hayati, Jakarta, Indonesia.

Ministry of Forestry (2008) Peraturan menteri kehutanan Nomor P.57/Menhut-II/2008 tentang arahan strategis konservasi spesies nasional 2008-2018. Ministry of Forestry, Jakarta, Indonesia.

Mittermeier, R.A. \& Mittermeier, C.G. (1997) Megadiversity: Earth's Biologically Wealthiest Nations. CEMEX, Mexico City, Mexico.

Mittermeier, J.C., Oliveros, C.H., Haryoko, T., Irham, M. \& Moyle, R.G. (2014) An avifaunal survey of three Javan volcanoes-
Gn Salak, Gn Slamet and the Ijen Highlands. BirdingASIA, 22, 91-100.

Myers, N., Mittermeier, R.A., Mittermeier, C.G., Da Fonseca, G.A.B. \& Kent, J. (2000) Biodiversity hotspots for conservation priorities. Nature, 403, 853-858.

Nijman, V. \& Sözer, R. (1996) Konservasi Elang Jawa dan jenis-jenis burung endemik Jawa lainnya: Daerah prioritas kawasan konservasi di Jawa Tengah [Conservation of the Javan Hawk-eagle and other endemic bird species on Java: Priority areas for protection in Central Java]. Technical Memorandum 11 Bogor, PHPA \& BirdLife International-Indonesia Programme, Bogor, Indonesia.

Nijman, V., Sari, S.L., Siriwat, P., Sigaud, M. \& Nekaris, A. (2017) Records of four Critically Endangered songbirds in the markets of Java suggest domestic trade is a major impediment to their conservation. BirdingASIA, 27, 20-25.

Nijman, V., Ardiansyah, A., Hendrik, R., Imron, M.A. \& NeKaris, A. (2020) The trade in rufous-fronted laughingthrush Garrulax rufifrons in Java, Indonesia. Forktail, 36, 74-78.

Phillips, S.J. \& Dudí, M. (2008) Modeling of species distributions with Maxent: new extensions and a comprehensive evaluation. Ecography, 31, 161-175.

Phillips, S.J., Dudí, M., Elith, J., Graham, C.H., Lehmann, A., Leathwick, J. \& Ferrier, S. (2009) Sample selection bias and presence-only distribution models: implications for background and pseudo-absence data. Ecological Applications, 19, 181-197.

Praptosumiryo, T.N. (2013) The rare pteridophytes of Mt. Slamet with three species new records for Java. Floribunda, 4, 138-146.

Pribadi, T., Raffiudin, R. \& Harahap, I.S. (2011) Termites community as environmental bioindicators in highlands: a case study in eastern slopes of Mount Slamet, Central Java. Biodiversitas, 12, 235-240.

Quinn, P.F., Beven, K.J. \& Lamb, R. (1995) The in $(a / \tan / \beta)$ index: How to calculate it and how to use it within the topmodel framework. Hydrological Processes, 9, 161-182.

Radula, M.W., Szymura, T.H. \& Szymura, M. (2018) Topographic wetness index explains soil moisture better than bioindication with Ellenberg's indicator values. Ecological Indicators, 85, 172-179.

Rahman, D.A., Rianti, P., Muhiban, M., Muhtarom, A., Rahmat, U.M., Santosa, Y. \& Aulagnier, S. (2018) Density and spatial partitioning of endangered sympatric Javan leopard (Felidae) and dholes (Canidae) in a tropical forest landscape. Folia Zoologica, $67,207$.

R Core Team (2020) R: A Language and Environment for Statistical Computing. R Foundation for Statistical Computing, Vienna, Austria.

Republika (2010) Jumlah Pendaki Gunung Slamet Meningkat 10 Kali Lipat [The number of Mount Slamet Climbers Increases 10 times]. republika.co.id/berita/nasional/daerah/16/05/10/06yej7365-jumlahpendaki-gunung-slamet-meningkat-10-kali-lipat [accessed 10 May 2020].

Rozendaal, F.G. (1989) Taxonomic affinities of Bradypterus montis. Dutch Birding, 11, 164-167.

Setiawan, A., Duunantoko, Bintari, A.W., Kusuma, Y.W.C., Pudyatmoko, S. \& Imron, M.A. (2007) Populasi dan distribusi Rekrekan (Presbytis fredericae) di lereng selatan Gunung Slamet Jawa Tengah. Biodiversitas: Journal of Biological Diversity, 8, 305-308.

Setiawan, A., Wibisono, Y., Nugroho, T.S., Agustin, I.Y., Imron, M.A., Pudyatmoko, S. \& Djuwantoko (2010) Javan Surili: a survey population and distribution in Mt. Slamet Central Java, Indonesia. Jurnal Primatologi Indonesia, 7, 51-54.

Setiawan, A., Nugroho, T.S., Wibisono, Y., Ikawati, V. \& Sugardjito, J. (2012) Population density and distribution of Javan 
gibbon (Hylobates moloch) in Central Java, Indonesia. Biodiversitas: Journal of Biological Diversity, 13, 23-27.

Sodhi, N.S., Koh, L.P., Clements, R., Wanger, T.C., Hill, J.K., Hamer, K.C. et al. (2010) Conserving Southeast Asian forest biodiversity in human-modified landscapes. Biological Conservation, 143, 2375-2384.

Sözer, R., Nijman, V., van Balen, S., Setiawan, I., Prawiradilaga, D.M. \& Subijanto, J. (1997) Javan Hawk-Eagle Recovery Plan/Recana Pemulian Elang Jawa. PHPH, FFI \& BirdLife Indonesia, Bogor, Indonesia.

SPECIES 360 ZIMS (2020) Rufous-Fronted Laughingthrush Studbook. Zoological Information Management Software, consulted 18 May 2020. Species 360, Minneapolis, USA.

Stattersfield, A.J., Crosby, M.J., Long, A.J. \& Wege, D.C. (1998) Endemic Bird Areas of the World: Priorities for Biodiversity Conservation. (Conservation Series 7) BirdLife International, Cambridge, UK.

Soemarno, S. \& Girmansyah, D. (2012) Kondisi kawasan hutan alam Gunung Slamet, Jawa Tengah. In Ecology of Mount Slamet: Geology, Climatology, Biodiversity and Social Dynamics (eds I. Maryanto, M. Noerdjito \& T. Partomihardjo), pp. 41-61. LIPI Press, Jakarta, Indonesia. [Indonesian]

Tognelli, M.F. (2005) Assessing the utility of indicator groups for the conservation of South American terrestrial mammals. Biological Conservation, 121, 409-417.

UNEP-WCMC \& IUCN (2019) The World Database on Protected Areas. UNEP-WCMC \& IUCN, Cambridge, UK.

USGS (U.S. Geological Survey) (2019) Earth Explorer. earthexplorer.usgs.gov [accessed 1 December 2019].

van Balen, S. (Bas), Eaton, J.A. \& Rheindt, F.E. (2013) Biology, taxonomy and conservation status of the short-tailed green magpie Cissa [t.] thalassina from Java. Bird Conservation International, 23, 91-109.
Venter, O., Fuller, R.A., Segan, D.B., Carwardine, J., Brooks, T., Butchart, S.H.M. et al. (2014) Targeting global protected area expansion for imperiled biodiversity. PLOS Biology, 12, e10o1891.

Wahyuni, S. \& Nasution, E.K. (2016) Studi populasi owa jawa (Hylobates moloch) di lereng Gunung Slamet Jawa Tengah. Biosfera, 33, 46-51.

Wearn, O.R. \& Glover-Kapfer, P. (2017) Camera-Trapping for Conservation: A Guide to Best-Practices. WWF, Woking, UK.

Whitten, T., Soeriaatmadja, R.E. \& Afiff, S.A. (1997) The Ecology of Java and Bali. Oxford University Press, Oxford, UK.

Wibisono, H.T., Wahyudi, H.A., Wilianto, E., Pinondang, I.M.R., Primajati, M., Liswanto, D. \& Linkie, M. (2018) Identifying priority conservation landscapes and actions for the Critically Endangered Javan leopard in Indonesia: conserving the last large carnivore in Java Island. PLOS ONE, 13, e0198369.

Widhiono, I. (2015) Diversity of butterflies in four different forest types in Mount Slamet, Central Java, Indonesia. Biodiversitas: Journal of Biological Diversity, 16, 196-204.

Widhiono, J., Sudiana, E. \& Sucianto, E.T. (2016) Insect pollinator diversity along a habitat quality gradient on Mount Slamet, Central Java, Indonesia. Biodiversitas: Journal of Biological Diversity, $17,746-752$.

Widodo, W. (2010) Studi keanekaan jenis burung dan habitatnya di lereng timur hutan Pegunungan Slamet, Purbalingga, Jawa Tengah. Bionatura, 12, 68-77.

Widodo, W. (2012) Keragaman jenis burung di hutan Gunung Slamet, Jawa Tengah. In Ekologi Gunung Slamet: Geologi, Klimatologi, Biodiversitas dan Dinamika Sosial (eds I. Maryanto, M. Noerdjito \& T. Partomihardjo), pp. 135-148. Pusat Penelitian Biologi-LIPI \& Universitas Sudirman, Purwokerto, Indonesia.

ZAR, J. (1999) Biostatistical Analysis. 4th edition. Prentice Hall, Upper Saddle River, USA. 